\title{
Peramalan Permintaan Inti Sawit (Kernel) di PT. Perkebunan Nusantara V Sei Pagar
}

\author{
Mhd Fauzan HM ${ }^{1}$, Nofirza ${ }^{2}$ \\ 1,2 Jurusan Teknik Industri, Fakultas Sains dan Teknologi, UIN Sultan Syarif Kasim Riau \\ Jl. HR. Soebrantas No. 155 Simpang Baru, Panam, Pekanbaru, 28293 \\ Email: fauzanhm04@gmail.com,nofirza@uin-suska.ac.id,
}

\begin{abstract}
ABSTRAK
Produksi inti sawit (kernel) yang berlebih di PT. Perkebunan Nusantara V Sei Pagar mengindikasikan produksi yang tidak direncanakan dengan baik. Akibatnya terdapat penumpukan sisa penjualan selama tahun 2016 yang jumlahnya mengalami kenaikan 2 kali lipat di bandingkan pada tahun sebelumya. Hal ini berdampak kerugian bagi perusahaan sejalan dengan menurunnya kualitas kernel jika lama disimpan. Tujuan pernelitian ini adalah memastikan ketepatan perencanaan produksi dengan melakukan peramalan permintaan kernel menggunakan metode eksponential smoothing, shingga dapat ditentukan jumlah optimal produksi kernel. Berdasarkan hasil pengolahan data menngunakan metode eksponential smoothing ini diperoleh, nilai alpha yang digunakan adalah 0,8 dengan nilai MAD sebesar 174.194.3, MSE sebesar 39599610000, MAPE sebesar 0,4, dan standar error sebesar 219.999. Pengujian hasil peramalan pada tracking signal menunjukan data hasil ramalan yang dilakukan menunjukkan nilai dibawah angka \pm 4 (yang berarti metode ini layak untuk digunakan). Dengan diperolehnya hasil perhitungan menggunakan metode exponential smoothing ini, diharapkan dapat menjadi solusi bagi perusahaan untuk mengurangi kelebihan produksi.
\end{abstract}

Kata Kunci: Exponential Smoothing, Peramalan, Perencanan Produksi

\section{Pendahuluan}

PT Perkebunan Nusantara V (PTPTN V) adalah perusahaan pengolahan kelapa sawit milik pemerintah, Terdapat banyak PTPN V yang tersebar di Provinsi Riau salah satunya adalah PT Perkebunan Nusantara V Sei Pagar di kabupaten Kampar. Di PTPN V Sei terdapat permasalahan dalam perencanaan produksi yang menyebabkan perusahaan memproduksi melebih permintaan dari konsumen sehingga menyebabkan stock kernel meningkat 2 kali dalam priode 1 tahun, dikarenakan inti sawit ini tidak bisa di simpan terlalu lama karena dapat menimbulkan jamur pada kernel, mengakibatkan kualitas dari kernel menurun. Berikut adalah tabel penjualan Inti Sawit dari bulan Januari 2016 sampai dengan Desember 2016:

Tabel 1. Rekapitulasi jumlah produksi kernel dan permintaan kernel dari bulan januari 2016-desember 2016

\begin{tabular}{|c|c|c|c|c|}
\hline No & Bulan & $\begin{array}{c}\text { Produksi } \\
(\mathbf{K g})\end{array}$ & $\begin{array}{c}\text { Permintaan } \\
(\mathbf{K g})\end{array}$ & $\begin{array}{c}\text { Sisa } \\
(\mathbf{K g})\end{array}$ \\
\hline 1 & sisa awal & - & - & 113.838 \\
\hline 2 & Januari & 447.168 & 518.980 & 42.026 \\
\hline
\end{tabular}

\begin{tabular}{|c|c|c|c|c|}
3 & Februari & 434.359 & 391.330 & 85.055 \\
\hline 4 & Maret & 686.998 & 677.350 & 94.703 \\
\hline 5 & April & 747.747 & 715.750 & 126.700 \\
\hline 6 & Mei & 512.496 & 543.650 & 95.546 \\
\hline 7 & Juni & 182.939 & 215.930 & 62.555 \\
\hline 8 & Juli & 459.169 & 427.020 & 94.704 \\
\hline 9 & Agustus & 596.883 & 635.620 & 55.967 \\
\hline 10 & September & 979.733 & 889.010 & 146.690 \\
\hline 11 & Oktober & 1.156 .394 & 942.700 & 360.384 \\
\hline 12 & November & 859.554 & 1.027 .400 & 192.538 \\
\hline 13 & Desember & 1.047 .669 & 978.770 & 261.437 \\
\hline
\end{tabular}




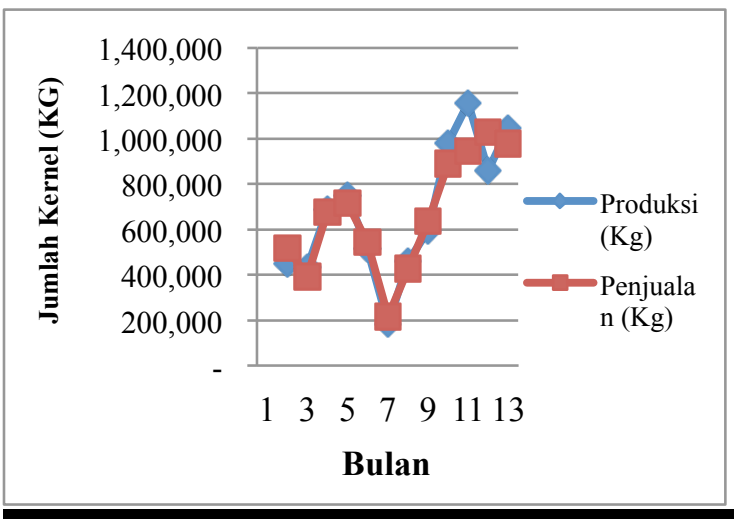

Gambar 1. Grafik perbandingan jumlah produksi kernel dan penjualan kernel bulan januari 2016-desember 2016

Dari Gambar 1 terlihat bahwa hasil produksi pada PT Perkebunan Nusatara V Sei Pagar ini cendrung acak dan di tiap bulan permintaan akan kernel pun berbeda, jika tidak ada perencanaan yang tepat maka perusahaan akan mengalami kerugian seperti produksi yang berlebihan yang menyebabkan perusahaan memerlukan biaya lebih untuk penyimpanan. Pada Tabel 1 dapat dilihat sisa produksi akhir bulan desember sangat besar yaitu mencapai $261.437 \mathrm{Kg}$ dan ini dapat dikategorikan sebagai waste karena perusahaan harus menyiapkan tempat dan biaya untuk penyimpanan. Jika dibandingkan dengan sisa pada awal tahun, jumlah ini meningkat lebih dari dua kali lipat, dan hal yang perlu dipertimbangkan bahwa penyimpanan kernel yang terlalu lama menyebabkan kualitas dari kernel menurun seperti berjamur dan juga kernel kehilangan minyaknya sehingga menjadi kering.

Agar pemborosan dapat dihindari diperlukan sebuah pengambilan keputusan yang tepat. Salah satu cara yang dapat dilakukan perusahaan untuk mengatasi permintaan kernel yang acak tersebut dan menghindaari produksi yang berlebihan adalah dengan meramalkan permintaan kernel mengunakan data histori penjualan mengunakan metode Exponential Smoothing.

\section{Metodologi Penelitian}

Berikut tahapan penelitian dapat dilihat pada flowchart

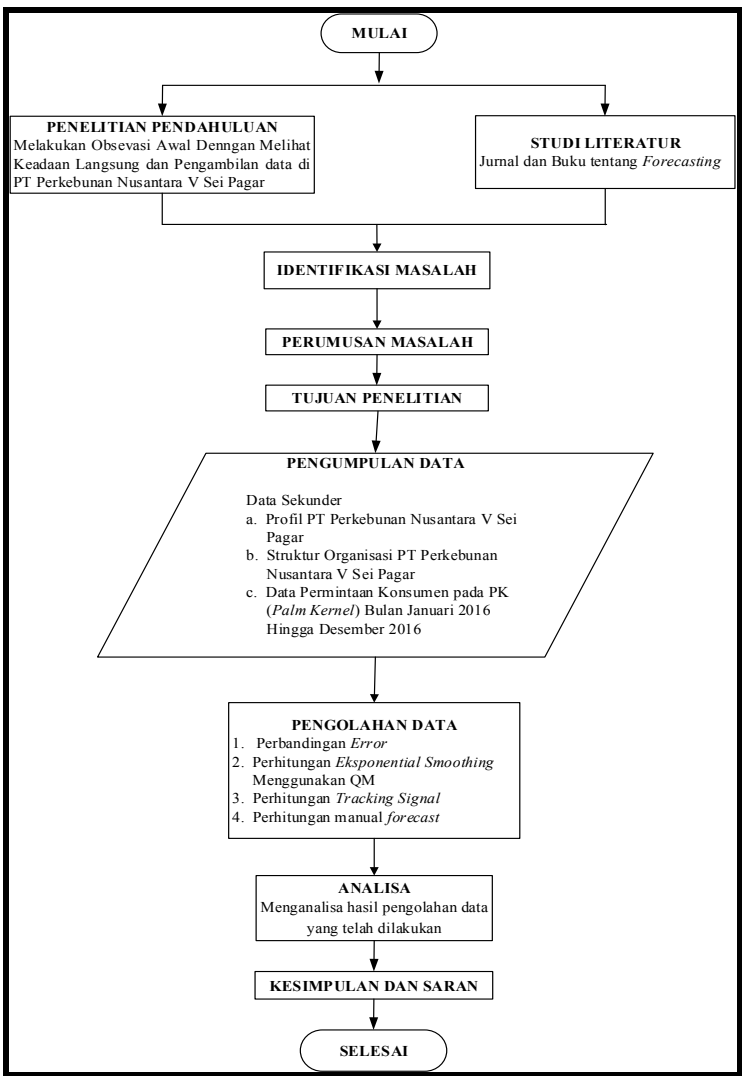

Gambar 2. Flowchart tahapan penelitian

\section{Hasil dan Pembahaan}

\section{Perhitungan dengan Metode Exponential Smoothing}

Metode smoothing diklasifikasikan menjadi dua kelompok, yaitu metode perataan dan metode pemulusan eksponensial (exponential smoothing) (Makridakis, 1999). Sesuai dengan pengertian konvensional tentang nilai rata-rata, metode perataan merupakan pembobotan yang sama terhadap nilai- nilai observasi. Metode-metode yang termasuk ke dalam kelompok metode perataan, antara lain (Munawaroh, 2010)

1. Rata-rata sederhana dari semua data masa lalu.

2. Rata-rata bergerak tunggal (single moving average) dari n nilai observasi yang terakhir.

3. Rata-rata bergerak ganda (double moving average) atau rata-rata bergerak dari rata-rata bergerak, yang akhirnya menjadi rata-rata yang berbobot tidak sama dan dapat digunakan dalam metode peramalan yang disebut rata-rata bergerak linear (linear moving average).

4. Rata-rata bergerak dengan orde yang lebih tinggi, tetapi metode ini jarang digunakan dalam peramalan praktis. 
Exponential Smoothing adalah suatu metode peramalan rata- rata bergerak yang melakukan pembobotan menurun secara exponential terhadap nilai-nilai observasi yang lebih tua (Makridakis, 1999). Metode exponential smoothing merupakan pengembangan dari metode moving average. Dalam metode ini peramalan dilakukan dengan mengulang perhitungan secara terus menerus dengan menggunakan data terbaru.

Secara matematis persamaan exponential smoothing adalah sebagai berikut (Sofyan, 2013).

$\mathrm{Y}^{\prime}{ }_{\mathrm{t}+1}=\alpha \mathrm{T}_{1}+(1-\alpha) \mathrm{Y}_{\mathrm{t}}^{\prime}$

Dimana:

$\mathrm{Y}^{\prime}{ }_{\mathrm{t}+1}=$ Nilai ramalan untuk periode berikutnya

$\alpha=$ Faktor konstanta pemulusan (0-1)

$\mathrm{T}_{1} \quad=$ Data pada periode $\mathrm{t}$

$\mathrm{Y}^{\prime}{ }_{\mathrm{t}} \quad=$ Rata-rata yang dimuluskan hingga periode $\mathrm{t}-1$

Nilai $\alpha$ yang menghasilkan tingkat kesalahan yang paling kecil adalah yang dipilih dalam permalan. Metode ini lebih cocok digunakan untuk meramal hal-hal yang fluktuasinya secara random atau tidak teratur (Garperz, 1998)

Pengolahan pada metode exponential smoothing ini menggunakan data permintaan, untuk membuat forecast dapat dimulai dari bulan february menggunakan data permintaan pada bulan Januari yaitu $518.980 \mathrm{Kg}$.

1. Bulan February

$\begin{aligned} \mathrm{Y}^{\prime}{ }_{\mathrm{t}+1} & =\mathrm{aT}+(1-\mathrm{a}) \mathrm{Y}^{\prime} \mathrm{t} \\ & =518980\end{aligned}$

2. Bulan Maret

$$
\begin{aligned}
\mathrm{Y}^{\prime}{ }_{\mathrm{t}+1} & =\mathrm{aT}+(1-\mathrm{a}) \mathrm{Y}^{\prime} \mathrm{t} \\
& =0,8 \times 391330+(1-0,8) \times 518980 \\
& =313.064+103.769 \\
& =416.860
\end{aligned}
$$

3. Bulan Desember

$$
\begin{aligned}
\mathrm{Y}^{\prime}{ }_{t+1} & =\mathrm{aT}+(1-\mathrm{a}) \mathrm{Y}^{\prime} \mathrm{t} \\
& =0.8 * 1.027 .400+(1-0.8) 919.93 \\
& =821.920+183.986,9 \\
& =1.005 .907
\end{aligned}
$$

Tabel 2. Rekapitulasi Peramalan Metode Exponential Smoothing

\begin{tabular}{|c|l|c|}
\hline No & Bulan & $\begin{array}{c}\text { Metode Exponential } \\
\text { Smoothing }\end{array}$ \\
\hline 1 & January & 518,980 \\
\hline 2 & February & 518,980 \\
\hline 3 & March & 416,860 \\
\hline 4 & April & 625,252 \\
\hline 5 & May & $697,650.4$ \\
\hline 6 & June & 574,450 \\
\hline
\end{tabular}

\begin{tabular}{|c|l|c|}
\hline 7 & July & 287,634 \\
\hline 8 & August & $399,142.8$ \\
\hline 9 & September & $588,324.6$ \\
\hline 10 & October & 828,873 \\
\hline 11 & November & $919,934.6$ \\
\hline 12 & December & $1,005,907$ \\
\hline
\end{tabular}

\section{Perbandingan Error}

Peramalan dikatakan baik juga hasil ramalan memiliki error yang kecil sehingga memungkinkan data peramalan yang dilakukan akan mendekati hasil permintaan sebenar nya.

Salah satu cara yang dapat dilkukan adalah membandingkan error pada ramalan dengan melihat beberapa faktor seperti metode yang di gunakan atau pun alpha yang digunakan, pada penelitian ini peneliti akan membandingkan error terkecil dengan melihat nilai alpha. Perbandingan alpha dilakukan dari nilai 0,0 hingga 0,8 .

Persamaan menghitung nilai error asli atau residual dari setiap periode peramalan adalah sebagai berikut :

et $=\mathrm{Xt}-\mathrm{St}$

Dimana:

et $=$ Kesalahan peramalan pada periode $\mathrm{t}$.

$\mathrm{Xt}=$ Data pada periode $\mathrm{t}$.

St $=$ Nilai peramalan pada periode $\mathrm{t}$.

Nasution (2008) dan lestari (2017) menyatakan bahwa Salah satu cara mengevaluasi teknik peramalan adalah menggunakan ukuran tentang tingkat perbedaan antara hasil peramalan dengan permintaan yang sebenarnya terjadi. Ada empat ukuran yang biasa digunakan, yaitu (Yuniastari, 2014):

a. Rata-rata Deviasi Mutlak (Mean Absolute Deviation $=$ MAD) MAD merupakan rata-rata kesalahan mutlak selama periode tertentu tanpa memperhatikan apakah hasil peramalan lebih besar atau lebih kecil dibandingkan kenyataannya. Secara metematis, MAD dirumuskan sebagai berikut: (

$$
\mathrm{MAD}=\sum\left|\frac{\mathrm{At}-\mathrm{Ft}}{\mathrm{N}}\right|
$$

Dimana :

$$
\begin{aligned}
\mathrm{At} & =\text { Permintaan Aktual pada periode }-\mathrm{t} . \\
\mathrm{Ft} & =\text { Peramalan Permintaan (Forecast) } \\
& \text { pada periode-t. } \\
\mathrm{N}= & \text { Jumlah periode peramalan yang } \\
& \text { terlibat. }
\end{aligned}
$$

b. Rata-rata Kuadrat Kesalahan (Mean Square Error = MSE). MSE merupakan metode alternatif dalam suatu metode peramalan. 
Pendekatan ini penting karena teknik ini menghasilkan kesalahan yang moderat lebih di sukai oleh suatu peramalan yang menghasilkan kesalahan yang sangat besar. MSE dihitung dengan menjumlahkan kuadrat semua kesalahan peramalan pada setiap periode dan membaginya dengan jumlah periode peramalan.

c. Rata-rata Persentase Kesalahan Absolut (Mean Absolute Percentage Error = MAPE). MAPE merupakan ukuran kesalahan relativ. MAPE biasanya lebih berarti dibandingakan MAD karena MAPE menyatakan persentase kesalahan hasil peramalan terhadap permintaan aktual selama periode tertentu yang akan memberikan informasi persentase kesalahan terlalu tinggi atau terlalu rendah. Secara matematis, MAPE dinyatakan sebagai berikut:

$\mathrm{MAPE}=\left(\frac{100}{\mathrm{~N}}\right) \sum\left|A t \frac{\mathrm{Ft}}{\mathrm{At}}\right|$

Dimana:

At $=$ Permintaan Aktual pada periode $-\mathrm{t}$.

$\mathrm{Ft}=$ Peramalan Permintaan (Forecast) pada periode-t.

$\mathrm{N}=$ Jumlah periode peramalan yang terlibat.

Tabel 3. Tabel perbandingan error

\begin{tabular}{|c|c|c|c|c|c|}
\hline Alpha & Bias & MAD & MSE & Standard & MAP \\
\hline .00 & 157795.5 & 252824.5 & 89178370000 & 330145 & .4 \\
\hline .10 & 136805 & 234511 & 74034570000 & 300810 & .4 \\
\hline .20 & 119190.7 & 221780.7 & 63718480000 & 279066.6 & .4 \\
\hline .30 & 103934.8 & 209512 & 56439380000 & 262643.2 & .4 \\
\hline .40 & 90541.3 & 196958.7 & 51158230000 & 250053.4 & .4 \\
\hline .50 & 78819.2 & 188164 & 47210830000 & 240212.7 & .4 \\
\hline .60 & 68694.2 & 181816.9 & 44146230000 & 232285.4 & .4 \\
\hline .70 & 60087.6 & 177315.3 & 41666900000 & 225668.4 & .4 \\
\hline .80 & 52865.7 & 174194.2 & 39599620000 & 219999 & .4 \\
\hline
\end{tabular}

Dari tabel 3 di atas dapat dilihat terdapat perbandingan nilai alpha dari 0,0 sampai 0,8 dan juga terdapat besaran error pada tiap-tiap nilai alpha yang mana fungsinya untuk melihat perbandingan error yang di hasilkan dari nilai alpha 0,0 hingga 0,8 . Setelah di bandingkan maka dapatlah alpha yang memiliki error yang terkecil adalah alpha dengan nilai 8 dengan nilai $\mathrm{MAD}=174194,2, \quad \mathrm{MSE}=39599620000, \quad$ Standar Error $=219999$, dan $\mathrm{MAPE}=0.4$. Sedangkan nilai alpha yang memiliki error terbesar adalah 0.00 dengan nilai $\mathrm{MAD}=252824.5$, $\mathrm{MSE}=89178370000$, Standar Error $=330145$ dan MAPE=0.4.

\section{Hasil Peramalan Exponential Smoothing}

Setelah dilakukan perhitungaan nilai error dengan antara alpha 0,0 hingga 0,8 maka selanjutnya adalah memasukan nilai alpha yang terpilih ke pengolahan data menggunakan sofeware QM. Nilai alpha yang di peroleh pada perhitungan perbandingan error adalah 0,8

a. Selanjutnya setelah nilai alpha diketahui maka masukan nlai alpha for smoothing dengan nilai 0,8 , selanjutnya klik solve.

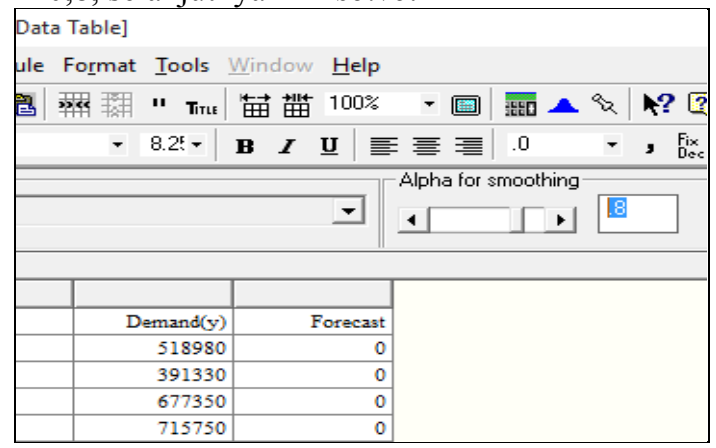

Gambar 3. Set alpha for smoothing

b. Setelah itu, maka didapatlah hasil perhitungan, berupa forecasting result, details and error analysis dan grafik perbandingan hasil peramalan dan data sebenarnya.

\begin{tabular}{|l|r|}
\hline \multicolumn{2}{|l|}{ Ga Forecasting Results } \\
\hline Measure & Valve \\
\hline Error Measures & 52865.6 \\
\hline Bias (Mean Error) & 174194.3 \\
\hline MAD (Mean Absolute Deviation) & 39599610000 \\
\hline MSE (Mean Squared Error) & 219999 \\
\hline Standard Error (denom=n-2=9) & .4 \\
\hline MAPE (Mean Absolute Percent Error) & 984197.4 \\
\hline Forecast & \\
\hline next period & \\
\hline
\end{tabular}

Gambar 4. Forecasting results metode exponential smoothing

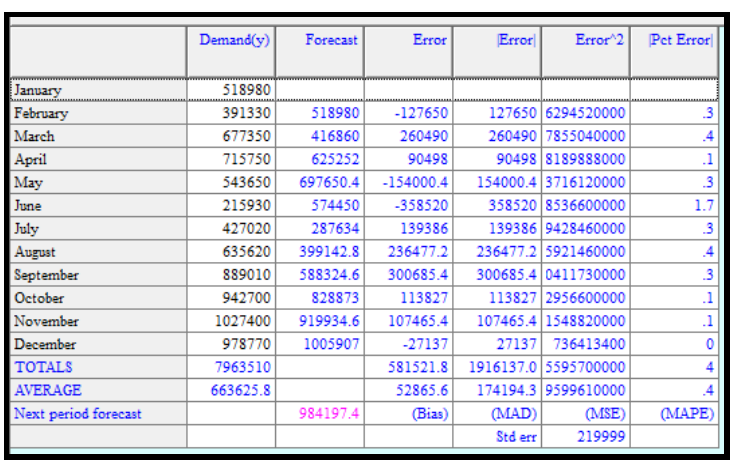

Gambar 5. Forecasting results dan tingkat error metode exponential smoothing 
Tabel 4. Rekapitulasi ukuran kesalahan metode exponential smoothing

\begin{tabular}{|c|c|}
\hline Error Measures & Exponential Smoothing \\
\hline MAD & 174194.3 \\
\hline MSE & 39599610000 \\
\hline MAPE & 0.4 \\
\hline Standar Error & 219999 \\
\hline
\end{tabular}

Tabel 5. Perbandingan Hasil Ramalan Terhadap Permintaan

\begin{tabular}{|c|c|c|c|}
\hline No & Bulan & Permintaan & $\begin{array}{c}\text { Hasil } \\
\text { Peramalan }\end{array}$ \\
\hline 1 & January & 518980 & 518980 \\
\hline 2 & February & 391330 & 518980 \\
\hline 3 & March & 677350 & 416860 \\
\hline 4 & April & 715750 & 625252 \\
\hline 5 & May & 543650 & 697650.4 \\
\hline 6 & June & 215930 & 574450 \\
\hline 7 & July & 427020 & 287634 \\
\hline 8 & August & 635620 & 399142.8 \\
\hline 9 & September & 889010 & 588324.6 \\
\hline 10 & October & 942700 & 828873 \\
\hline 11 & November & 1027400 & 919934.6 \\
\hline 12 & December & 978770 & 1005907 \\
\hline 13 & Total & 7984510 & 7504720 \\
\hline
\end{tabular}

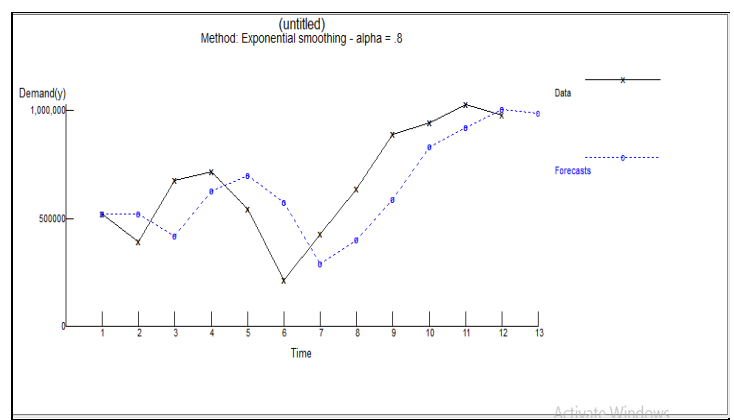

Gambar 6. Grafik perbandingan hasil ramalan terhadap permintaan

Dari gambar diatas dapat di lihat bahwa hasil ramalan yang di peroleh jika dibandingkan dengan permintaan aktual tidak terjadi perubahan yang signifikan, hal ini dikarenakan nilai alpha yang digunakan cukup tinggi yaitu 0,8 .

\section{Tracking Signal}

Keandalan dari model peramalan terpilih dengan Regresi Linear dibangun dengan peta kontrol Tracking Signal. Tracking Signal didefinisikan sebagai Running Sum of the Forecast Error (RSFE) dibagi dengan Mean Absolute
Deviation (MAD), sebagai berikut (Gasperz, 1998):

Tracking signal $=\frac{R S F E}{M A D}$

\section{RSFE $=\sum$ Demand in Period $i-$ Forecast in Period $i$}

Tracking Signal yang positif menunjukkan bahwa permintaan aktual lebih besar dari ramalan, sedangkan Tracking Signal negatif menunjukkan bahwa permintaan aktual lebih kecil dari ramalan. Beberapa ahli dalam sistem peramalan seperti Geoge Plossl dan Oliver Wight menyarankan untuk menggunakan nilai \pm 4 sebagai batas kontrol Tracking Signal. Jika Tracking Signal melewati batas tersebut, hasil peramalan perlu ditinjau kembali karena akurasi peramalannya tidak bisa diterima. Nilai Tracking Signal dianggap baik jika perbandingan antara Possitive Error dan Negative Error sama banyaknnya dan nilai Tracking Signal mendekati 0 (Gaspersz, 1998).

Model Tracking Signal untuk metode exponential smoothing (Tabel 6).

Tabel 6. Nilai tracking signal

\begin{tabular}{|l|c|c|c|}
\hline \multicolumn{1}{|c|}{ Bulan } & Demand $(\mathrm{Y})$ & Forecast & $\begin{array}{c}\text { Tracking } \\
\text { Signal }\end{array}$ \\
\hline January & 518980 & 518980 & - \\
\hline February & 391330 & 518980 & -1 \\
\hline March & 677350 & 416860 & 0,7 \\
\hline April & 716750 & 625252 & 1,4 \\
\hline May & 543650 & 697650.4 & 0,4 \\
\hline June & 215930 & 574450 & $-1,5$ \\
\hline July & 427020 & 287634 & $-0,8$ \\
\hline August & 635620 & 399142.8 & 0,4 \\
\hline September & 889010 & 588324.6 & 1,9 \\
\hline October & 942700 & 828873 & 2,5 \\
\hline November & 1027400 & 919934.6 & 3,2 \\
\hline December & 998770 & 1005907 & 3,3 \\
\hline
\end{tabular}

Berikut Peta Kontrol Tracking Signal model peramalan eksponential smoothing dengan Upper Control Line +4 \& Lower Control Line -4 


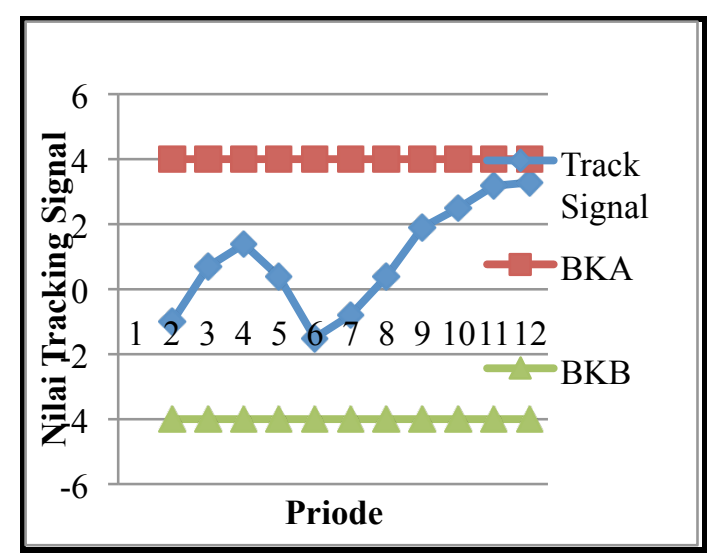

Gambar 7. Grafik Tracking Signal Exponential Smoothing

Dari grafik tracking signal exponential smoothing diatas dapat dilihat data Tracking Signal didapati 3 priode memiliki nilai negatif yang berarti terdapat 3 bulan permintaan inti sawit aktual lebih kecil dibandingkan dengan ramalan dan terdapat 8 priode memiliki nilai positif yang berarti permintaan aktual lebih besar dari peramalan. Dari keseluruhan data yang diperoleh pada tracking signal tidak ditemukan priode data yang melebihi batas kontrol atas dan batas kontrol bawah yang berarti hasil ramalan yang dilakukan dengan menggunakan metode exponential smoothing pada permintaan inti sawit di PT Perkebunan nusantara V Sei Pagar dapat diterima, meskipun hasil yang diperoleh tidak sangat baik hal ini dikarenakan perbandingan antara nilai positif dan negatif pada tracking signal tidak seimbang dan nilai tracking signal yang dihasil pun masih agak jauh dari nilai 0 . Dengan jelas, bahwa hasil penelitian ini dapat membantu proses pengambilan keputusan bagi perusahaan. Lestari (2016) mengatakan bahwa hasil peramalan dapat membantu dalam proses perencanan pengandaan barang dan logistic perusahaan.

\section{Kesimpulan}

Berdasarkan pengolahan data dan analisa yang telah dilakukan, maka diketahui bahwa forecasting dengan metode peramalan exponential smoothing dengan nilai alpha 0.8 diperoleh hasil yang tidak berbeda secara signifikan antara data yang di forecast dan hasil forecast, sehingga dapat disimpulkan bahwa metode ini dapat (layak) digunakan untuk perencanaan produksi kedepannya.

\section{Daftar Pustaka}

[1] Gasperz, Vincent. Production Planning and Inventory Control. Jakarta: Gramedia Pustaka Utama. 1998.
[2] Ginting, Rosnaini. Sistem Produksi. Yogyakarta: Graha Ilmu, 2007

[3] Makridakis dan Steven Wheelwright. Metode \& Aplikasi Peramalan, Jilid1. Tangerang: Binarupa Aksara Publ., 1999

[4] Munawaroh, Astin Nurhayati. "Peramalan Jumlah Penumpang Pada PT. Angkasa Pura I (Persero) Kantor Cabang Bandar Udara Internasional Adisutjipto Yogyakarta Dengan Metode Winter's Exponential Smoothing \& Seasonal Arima”. UNY. Yogyakarta, 2010

[5] Nasution, A. H, Prasetyawan. Perencanaan dan Pengendalian Produksi. Yogyakarta: Graha Ilmu, 2008

[6] Lestari, Fitra., Anwar, Ulfah., Nugraha, Ngestu., Azwar, Budi. Forecasting Demand in Blood Supply Chain (Case Study on Blood Transfusion Unit). Proceedings of the World Congress on Engineering 2017 Vol II, London UK. 2017.

[7] Sofyan, Diana Khairani. Perencanaan \& Pengendalian Produksi. Lhokseumawe NAD: Graha Ilmu, 2013

[8] Subagyo, Pangestu. Forecasting Konsep dan Aplikasi. Jakarta : BPFE, 2002

[9] Yuniastari, Ni Luh Ayu Kartika., IGP Wirarama Wedashwara Wirawan. "Peramalan Permintaan Produk Perak Menggunakan Metode Simple Moving Average \& Exponential Smoothing”. STIKOM Bali, 2014

[10] Lestari, Fitra. Manajemen Logistik. Almujtahadah. 2016. ISBN : 9786029392807. 